\title{
The rise of the European
}

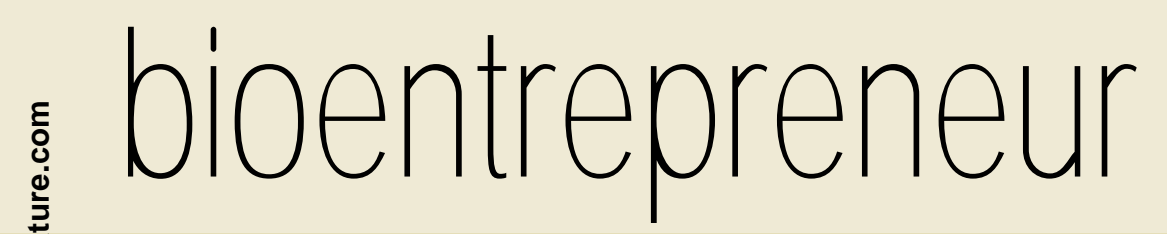

After many fits and starts, European biotechnology is finally gaining steam, despite institutional and cultural obstacles facing would-be entrepreneurs, says Joe Alper.

our years ago, when $N$ ature Biotechnology asked the question "Is the practice of bioentrepreneurship and biotechnology global?", the answer was a qualified no ${ }^{1}$. Certainly, Europe and to a much lesser extent Japan were developing their own biotechnology sectors, but the United States was the world leader in terms of the number of dedicated biotechnology firms, the amount of capital they raised, and the number of patents and revenues they generated.

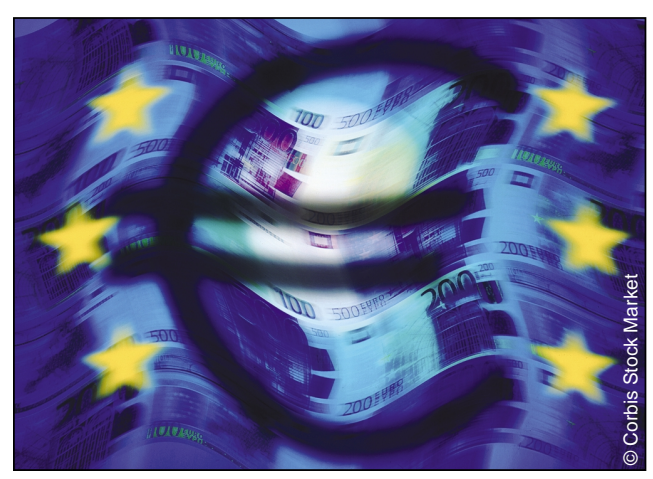

Today, Europe has closed that bioentrepreneurship gap, at least in some respects. Based on the total number of companies, Europe is now the surprise leader in the field. According to 2001 figures from the US Biotechnology Industry Organization (BIO; Washington, DC) and the Biotechnology Information Databank (BID) maintained at the University of Siena (Italy), there are 2,104 dedicated biotechnology companies in Europe and 1,379 in the United States. And although the absolute numbers of companies (and employees) are still smaller than in the United States, employment by European companies has jumped, as has the amount of money they have raised in both the private and public equity markets globally. The total revenue generated by biotechnology firms in Europe is now growing at about the same rate as in the United States, albeit from a much smaller base.

However, European biotechnology companies are on average much smaller than thosein North America. Only $10 \%$ of

Joe Alper is a freelance writer working in Louisville, C0 (ja@nasw.org). fewer than 20 people. "One of our biggest problems here in Europe is finding entrepreneurs who know how to run a small company," says Herbert Reutimann, managing director of Unitectra (Zurich,

Switzerland), the technology transfer arm of the Universities of Berneand Zurich. "We've got plenty of people coming out of big pharma who think they can be entrepreneurs, but the great majority of them aren't suited to the small company life."

Then again, almost half of Europe's biotechnology companies have come into being since January 1996, although their relativeyouth does not completely explain the preponderance of microcompanies. Indeed, nearly $70 \%$ of Swedish biotechnology companies employ fewer than 10 people, even though Sweden has a far greater percentage of companies created before 1991 and a larger percentage created after 1996 than do other European countries. Potentially, restricted access to capital could beconstraining their growth.

Still, bioentreneurship, it seems, has found its footing across much of Europe after only slow growth over the past two decades. "It's been a long time coming, but it's now a good time to be an entrepreneur in biotech in Europe," says Glenn Crocker, a member of Ernst \& Young's H ealth Sciences Group (Cambridge, UK). "Researchers are coming up with some interesting, solid business plans and European investors are finally responding positively by putting an unparalleled amount of money into European biotechnology companies instead of taking the 'safe' road and investing it [ in biotechnology companies] in the United States."

Perhaps buoyed by private-sector action, even the European Union (EU) seems to be jumping on the biotechnology bandwagon. At their most recent summit in Barcelona this past $M$ arch, EU leaders endorsed a plan to "develop measures and a timetable which 
enable Community businesses to exploit the potential of biotechnology." Philippe Pouletty, president of France Biotech (Paris) and a former entrepreneur in the United States ( see page BE8), says: "This is a remarkable development, and if the governments of Europe now follow through with action, the coming years should be very good for biotech here."

\section{Where are the entrepreneurs?}

Though Europe as a whole is seeing an acceleration of new company formation, European biotechnology has not flowered uniformly across the continent. A 2001 study by the European Commission on Competitiveness found that Germany, which has more than 500 independent biotechnology firms, and the U nited Kingdom, which has slightly fewer, account for about one-half of the total number of dedicated biotechnology companies in Europe. France ranks third, with just under 350 companies, followed by Sweden with nearly 230 companies- though, as mentioned above, the growth of Sweden's biotechnology industry has lagged behind that of the rest of Europeover the past six years. Switzerland, the N etherlands, Italy, Belgium, Finland, Denmark, Ireland, Norway, and Spain each have 50-100 biotechnology companies. H owever, on a per capita basis, Sweden ranks first, followed by Switzerland, I reland, Finland, and Denmark (see Table 1).

According to data from the BID, technical specialization and area of focus vary by country. For the whole of Europe, $40 \%$ of all independent biotechnology companies are developing human therapeutics, and slightly more than $20 \%$ focus on diagnostics.

German biotechnology firms are active mainly in human health, whereas Swedish concerns concentrate on human and animal therapeutics. France, Italy, and Switzerland have a higher proportion of companies activein the agriculture-food arena.

Although it is simplistic to generalize, a large proportion of French and German biotechnology firms entered the industry to explore the commercial value of recent technological advances in genomics, proteomics, and bioinformatics. British firms are capitalizing on strengths in cell and tissue engineering, process biotechnology, instrumentation, and devices, as well as in combinatorial chemistry. Italian firms are carving out a niche developing antimicrobial and antiviral agents, whereas Swedish companies are specialists in biomaterials and in innovative technologies for drug discovery, such as chiral drug synthesis.
As in the United States, biotechnology companies in Europe tend to cluster around academic centers of excellence. In Europe, the highest densities of biotechnology companies are found in Cambridge, Oxford, London, Stockholm, and Zurich. Other clusters, such as those in the Munich, Rhine/Neckar, and Rhineland regions of Germany, the Île de France and Rhône-Alpes regions of France, and the Medicon Valley (a region spanning Denmark and southern Sweden, and see Nat. Biotechnol. 20, 433-435, 2002) have developed thanks to specific government programs designed to foster the growth of biotechnology in specific regions, particularly those regions that include established pharmaceutical companies.

An analysis of patent data by the Organization for Economic Cooperation and Development (OECD; Paris) shows that for the most part the countries leading the European biotechnology boom are those that lead Europe in the generation of intellectual property. Considering both US and European patents, Germany, the United Kingdom, and France generate significantly more patents than any other European country, although on a per capita basis, the N etherlands, Denmark, Switzerland, Belgium, and Sweden lead the continent. But, befitting US leadership in biotechnology entrepreneurship, US inventors have been granted nearly three times as many US patents and about 50\% more European patents as compared with their European counterparts.

\section{Cultural and psychological barriers}

Yes, bioentrepreneurship is

alive in Europe, but the

OECD patent analysis

shows one way in which European bioentrepreneurs are still playing catch-up with their US counterparts. Looking at a subset of "highly cited" biotechnology patents- those receiving at least 10 citations from other inventors, which often represent seminal discoveries- the OECD found a distinct technological edge for US biotechnology companies. Together, US and European biotechnology companies held $48 \%$ of these key patents, but U S companies accounted for morethan
$80 \%$ of that total. And among the highly cited patents held by European inventors, over three-quarters belong to large pharmaceutical and chemical companies, with virtually all of the remainder held by British biotechnology companies.

"What we see in Europe is that large, established companies are still funding most of the innovative research in the biotechnology and pharmaceutical areas," says

Reutimann. "I t hasn't become as common yet in Europe as it is in the US, where universities will patent the discoveries of their professors and then let the academics start their own companies."

To help remedy this situation, universities across the continent are following America's lead, setting up institutions, such as Unitectra in 1996, to foster the movement of research discoveries into startup biotechnology firms. Nevertheless, there is still much work to be done. "Culturally, we're fighting an uphill battle," says Reutimann.

"Entrepreneur is still a dirty word among many professors in the biological sciences. Europe is still a couple of decades behind the United States in that regard."

European entrepreneurs themselves complain that even when they are prepared to make the break with established conventions, they cannot find the necessary business talent to help them turn ideas and intellectual property into a going concern. "In the United States, you have people who are on their second or third company al ready and who have gained the business experience you need to deal with venture capitalists and potential customers," says Pedro de Noronha Pissarra, chief executive officer of Biotecnol

\begin{tabular}{lcc}
$\begin{array}{l}\text { Table 1. The number of biotechnology companies per } \\
\text { capita for nations in Europe (December 2000) }\end{array}$ \\
$\begin{array}{lcc}\text { Number of } \\
\text { dedicated biotech } \\
\text { companies }\end{array}$ & $\begin{array}{c}\text { Companies } \\
\text { per million } \\
\text { inhabitants }\end{array}$ \\
Country & 235 & 26.0 \\
\hline Sweden & 93 & 12.6 \\
Switzerland & 39 & 11.2 \\
Ireland & 53 & 10.4 \\
Finland & 51 & 9.6 \\
Denmark & 37 & 8.3 \\
Norway & 448 & 7.6 \\
United Kingdom & 504 & 5.9 \\
Germany & 342 & 5.8 \\
France & 55 & 5.4 \\
Belgium & 79 & 5.0 \\
Netherlands & 11 & 1.4 \\
Austria & 64 & 1.1 \\
Italy & 32 & 0.8 \\
Spain & &
\end{tabular}

Source: BID, University of Siena 
(O eiras), Portugal's largest dedicated biotechnology company. "The industry is still too young here in Europe to have those kinds of resources to draw on."

The result, say many who are close to the industry, is that investors remain reluctant to provide budding entrepreneurs with the necessary capital to get their young companies off the ground. "Venture capitalists in Europe, though they are become a little looser with funds, are still uncomfortable giving sizable amounts of money to unproven entrepreneurial talent," says Kevin Wilson, a former investment banker who consults for several European venture capital firms. This tightfistedness, he says, is the major reason why so many companies get stuck at the microcompany stage.

\section{An improving environment}

Those bioentrepreneurs who are succeeding, however, say that things are changing for the better. "It used to be that if you wanted to start a [biotechnology] company, you'd have to do it in the United States," says Pouletty, who took that route himself to start three companies, including SangStat (Fremont, CA), a biotechnology firm developing drugs for the organ and bone marrow transplant market. But he and other European biotechnology watchers say that the environment in Europe as a whole has improved greatly in three important respects.

To begin with, entrepreneurialism is starting to become a part of the science culture in Europe. "Peoplelike myself go to the States for graduate school or to do a postdoc, and we see firsthand that entrepreneurism is ingrained in the minds of our American counterparts and that this is an acceptable attitude to have," says Wolfgang Renner, chief executive officer and founder of Cytos (Zurich). Swiss colleague Dominik Escher, founder of functional genomics firm Esbatech (Zurich), adds: "Even academics are coming around, so that if they aren't interested themselves in becoming entrepreneurs, they don't discourage their students from following that path."

Second, governments have taken a variety of actions to encourage bioentrepreneurship. On a continent-wide basis, Europe has finally moved to make it easier to win biotechnology patents, something that entrepreneurs have demanded for at least a decade, and the EU recently voted to raise spending on research and development to $3 \%$ of gross national product, with an accompanying goal of putting some of that funding toward improving technology transfer between academia and developing industries.

On the local front, several nations have taken their own steps to encourage bioentrepreneurship within their borders.

Germany's BioRegio program was perhaps the most aggressive form of government action taken to date, one that many in the business credit for the huge increase in the number of German biotechnology companies (but see N at. Biotechnol. 20, 441-444, 2002). France's Innovation Law now allows academics to work directly with private companies, which has led to the formation of 100 new firms over the past three years. M ore recently, France committed $€ 90$ million to provide seed funds to new biotechnology companies and another $€ 90$ million to guarantee some $€ 400$ million in loans.

Countries have also taken more subtle actions. Switzerland, for example, created a faculty position at the Swiss Technical Institute in Lausanne (EFPL) to teach entrepreneurial skill to graduates, and to set up programs to actively encourage bioentrepreneurship in the country. Jane Royston, who saysher chaired faculty position at EFPL is one of a handful of similar ones created recently throughout Europe, says that having the official backing of a major state university has given a tremendous push to entrepreneurial activity in the life sciences. "We've been able to line up a lot of support both within the academic institutions and within the investor and business community," says Royston. Based on her program's success, she recently became an official advisor to the Swiss government, which has finally realized that biotechnology fits well with the nation's propensity for high-value added businesses.

The third way the business environment has improved in Europe is perhaps the most important-the opening of Europe's borders means more money is available to fund biotechnology ventures across the continent. "We're seeing some big venture funds with hundreds of millions of dollars being raised specifically for biotechnology in Europe, and that money now seems to cross borders freely," says Royston. O ne potential downside to this movement is that it is likely to drive local venture capitalists in smaller countries, such as Portugal, out of business. "And then how will a Portuguese biotech will get the money it needs?" asks de N oronha Pissarra. "It's going to be very difficult at that point to attract the attention of a venture firm in Switzerland or London."
The development of stock exchanges geared toward smaller companies, such as Germany's N euer M arket and EASDAQ , has also played an important role. "A bigadvantage the Americans have had is the ready access to the public equity markets, which gives the venture capitalists an out and a source of money to grow a company, so it's encouraging to see these markets growing here in Europe," says E\&Y's Crocker. Without a viable large bourse for smaller companies, the liquidity of stocks, even after going public, is poor, and venture capitalists find it hard to retrieve their investment in their portfolio companies, and for companies to float additional offerings to raise more money

\section{Will Europe always play second fiddle?}

Headds, though, that unless Europe's stock markets begin consolidating (possibly through the evolution of a EuroN M ) they will never create a big enough market to provide the liquidity that investors want to see beforehanding over money to a smaller firm. "We've made progress, but Europe needs to take the next step and do away with the fragmentation [ of the stock markets] that we now have or European biotechnology will always bebehind the United States," says Crocker.

The other factor that could permanently relegate Europe to playing second fiddle to America is the "first-mover" status that the United States has long enjoyed. A 2001 European Commission report stated the problem this way: "In technologies where innovative activities are often characterized by increasing returns, first-mover advantages are an important phenomenon and are likely to provide long-lasting and difficult to erodeleadership. European biotechnology firms may have simply been preempted by their American counterparts, while the excellence of the American scientific research system has attracted financial and human resources from all parts of the world, further strengthening US leadership in biotechnology."

Europe's hope, according to the Commission, lies with the fact that today's rapid rate of innovation in the life sciences provides undiscovered areas where no nation holds the upper hand. With the current rise in biotechnology and the infrastructure to support it, Europe's bioentrepreneurs may now be ready to seize opportunities when they arise.

1. Persidis, A. Bioentrepreneurship around the world. Nat. Biotechnol. 16 (suppl.), 3-4 (1998). 